\title{
Greig Syndrome
}

National Cancer Institute

\section{Source}

National Cancer Institute. Greig Syndrome. NCI Thesaurus. Code C35255.

An autosomal dominant genetic disorder caused by mutations in the GLI3 gene. It is characterized by physical abnormalities of the fingers and/or toes (extra fingers and/ or toes, fusion of the fingers and/or toes), large size head with prominent forehead and hypertelorism. 